\title{
Motivation leading to radicalization in terrorists
}

\begin{abstract}
A terrorist group commits acts of violence to produce wide spread fear to obtain worldwide recognition by attracting the attention of the media. They harass, weaken or embarrass government security, discourage foreign investments and tourism that can affect the target country's economy and influence government decisions and satisfy vengeance. The use of technology in the service of criminal investigations and the application of scientific techniques to detect and evaluate criminal evidence has advanced the criminal justice system throughout the country. When criminals erase all the evidences of their involvement scientific and highly sophisticated methods of Narco analysis, Polygraph and Brain Mapping tests collectively called deception detection tests are required to trace the involvement of criminals. The techniques of Narco analysis are helpful in tracking out the hidden information from the terrorist. A terror attack in the present study is on series of 7 bomb blast that took place on the suburban railway on 11th July 2006 at Mumbai, India. Understanding varied terrorist motivations and behaviors at the individual level can provide insight into the causes of particular behaviors. This study is an effort to help Government to improve counterterrorist methods and Policies understanding the behavior is important. Behavior of a terrorist varies depending on their individual intelligence, education, finance and their affiliation to organization. Perceived injustice, religion, identity, belonging, political activity, heroism and autonomy can be seen as strong influence, real causes and psychological motivation for an individual joining and staying with the terrorist groups. Post argues that "individuals become terrorists in order to join terrorist groups and commit acts of terrorism." Joining a terrorist group gives them a sense of revolutionary heroism and self-importance that they previously lacked as individuals. The results also indicate that the data in correlation with identity theory, humiliation-revenge theory and group socialization theory.
\end{abstract}

Keywords: terrorists, bomb blast, motivation, narco analysis, Mumbai

\author{
Volume 6 Issue 4 - 2018
}

\author{
Malini Subramanyam \\ Forensic Science Laboratory, India
}

Correspondence: Malini Subramanyam, Assistant Director, Forensic Science Laboratory, Bangalore, Karnataka, India, Tel 080-222943150,Email malinisubramanyam@gmail.com

Received: February 17, 2017| Published: August 28, 2018

\section{Introduction}

Word "Terrorism" in recent times refers to the killing of innocent people by a group in a way to create feelings of panic among the people of the nation. Terrorism is a global threat. Threats from terrorist groups have grown alarmingly and pose a greater challenge to the nations. Terrorists conduct their activities with the aim of destruction. The fear of terrorism is looming large in our daily life. There are innumerable incidents of such fear and insecurity. The numerous resources allocated to the task of preventing terrorism by the government sectors have not been completely fruitful in their processes. That is because these efforts often lack a foundation for understanding terrorists and their acts of violence.

A terror attack on India is not a new story. India has been continuously attacked. To count a few-cannaught Place (Delhi), Mehrauli (Gurgaon), Gaffar market (Karol Bagh, Delhi), Varanasi (Uttar Pradesh). The places chosen by the attackers were the most crowded places so as to kill the maximum people and create panic in the society. But Mumbai attack on July $11^{\text {th }}, 2006$ has shocked the commuters in the train as well as the Indian economy. These attacks have affected the major industries of the country and have directly hit the Aviation and Hotel industry. Various studies have been done to measure the magnitude of the effect of this unanticipated event. Present study examines the behavior of terrorists in one such unanticipated event serial train attacks in Mumbai on $11^{\text {th }}$ July 2006 wherein series of 7 bomb blast took place over a period of 11 minutes on the suburban railways.
Mumbai has managed to transform itself to from textile industry to a powerful financial capital of the country. Such growth in the city has become target for the terrorists attack that desire to shed India success. In 1992 and 1993 Hindu-Muslim riots claimed 1000, in 2003, 60 people were killed in car bombs, in July 2006189 people were killed and injured 899 by coordinated bombs that set off in pressure cookers ripped through commuter trains in the crowded city. November 26, 2008 attack on the Indian Stock market, attack on five star hotels has raised a question of security for the elite visitors. Terrorists often seem to employ irrational justifications for their target selections, and often seek goals that appear unattainable under rational evaluation. Fathali Moghaddam ${ }^{1}$ uses a staircase metaphor to show how individuals go through increasing stages of radicalization, where at each successive step the individual develops an increased sense of persecution and an increased engagement with normative justifications for violence. At the fifth and final step, the individual is ready and willing to commit a terrorist act, without any apparent sympathy for his or her potential victims. McCauley \& Moskalenko ${ }^{2}$ have a somewhat similar model, and discuss a pyramid of radicalization, the apex of which is the terrorist act, and the slopes of which represent the diminishing number of people who enter into such a radical mindset. They identify twelve drivers for radicalization, ranging from strongly personal to strongly social motivations. Yet while these theories shed some light on the individual terrorist, they lack the broader social perspective which could explain why feelings of radicalization may arise in the first place, and instead focus on their transmission and growth within an individual. 
The principle of the Indian legal system is based on the fact that until proved guilty, a person is innocent and we cannot convict innocents even if we need to surrender hundreds of criminals. In the present changing paradigm terrorists have started using newer techniques for committing the crime. The newer scientific techniques of Narco analysis are helpful in tracking out the hidden information from the terrorists. The technique of Narco analysis according to Hanscom $\mathrm{CB}^{3}$ states solution for better crime management is to promote the drug technique in the crime investigation. This technique aid in identification of the individual participated in the terrorist activity, helps in identifying the trained terrorist who have intentions to commit the act, help in identifying the financial supporters who are associated with the terrorist activities, helps in identifying the targets of attack, helps in identifying the leaders and their role in the terrorist organization. The use of such information along with the psychological principles and theories will give a better understanding of the terrorists' psychology.

The purpose of this study is to focus attention on the types of individual's motivation and how it differs from the others motivation. This study is an effort to help the Government to improve counterterrorist methods and policies. There appears to be a general agreement among psychologists who have studied the subject that there is no one terrorist mindset. The fact that there is no proper understanding of terrorists psychology has created a void in many levels such as policy-level decisions about how a state should respond to terrorism; at individual-level decisions about whether a given person of interest promoting extremist ideas truly poses a serious threat to the citizens of India, its assets and the interests. Why and how a person becomes terrorist and what motivates him to show violent attitude/ behavior needs to be understood first for implementing appropriate decision making process.

\section{Methods}

The present study is on the Mumbai attack on July $11^{\text {th }}, 2006-$ a serial train blast on the commuters in the train which killed 189 people and injured 829 commuters. Terrorists involved had taken care to erase all the evidence of their involvement and some terrorists had even managed to escape from the country after the incident. In such a case, scientific and highly sophisticated methods were required to trace the involvement of criminals. Law, science and technology have a great relevance in our lives. Law and science encounter each other in many ways. To protect legal rights and to strengthen the evidence, the help of scientific techniques are required. Manu Saxena ${ }^{4}$ working as a Judicial Assistant at Allahabad High Court in her article says Narco analysis, Polygraph and Brain Mapping tests collectively called deception detection tests (DDT) are scientific methods of interrogation techniques which are a simple and civilized way of identifying the criminals. In such situation, when all the evidences are erased, the human mind is the only place which gathered conclusive evidence relating to a crime. Most of the crimes are taking shape in the mind of a person, execution are stored as experiential knowledge. Scientific techniques of Brain mapping and Narco-analysis are the apt mechanism to identify such information hidden in the minds of person. Narco-analysis is said to be the best resort in cases where evidence is erased and one has no clue to identify the criminals. In India, the test of Narcoanalysis has been conducted since 2000 in Karnataka by "The Bangalore Forensic Sciences Laboratory".

In the present study 10 male individuals who were suspected to be involved in the serial train blast at Mumbai packed suburban train on July $11^{\text {th }}$, 2006 were brought for identifying their involvement in the case by the Anti terror squad (ATS) Mumbai. All subjects were healthy, free of cognitive deficits and were not using any psychoactive or psychotropic substances at the time of tests. A questionnaire was administered during the preliminary interaction to assure that the subjects do not present any impairment in their physical and mental health so as to prevent the contamination of the results. The questionnaire also aimed to identify the personal details of the subjects. All the suspected terrorists were permitted by the Hon'ble jurisdiction court for subjecting them for the scientific test of Narco analysis. Suspect terrorists were sent to local Government hospital to obtain the fitness certificate for the Narco analysis test by the cardiologists before subjecting them for the test. Physicians and anesthetists evaluated their medical reports. Informed consent was obtained by the suspects. After the approval by the ethical committee of the Government Hospital the procedure for the Narco analysis was initiated at the Operation Theatre along with the team. The procedure was followed as per the guidelines issued by Ministry of Home Affairs, Government of India. All the physiological parameters were monitored continuously during the entire procedure. The revelations made during the trance state were only video recorded. The information so revealed was further cross checked by subjecting the suspected terrorists to the brain mapping test at the later stage.

The Narco analysis test was conducted at the Operation theatre (O.T) in a General hospital along with the team. The team consists of physician, forensic expert, anaesthetist, scientific assistant, O.T. nurse and attender. The suspected terrorist was attached to the BIS monitor along with other gadgets in the O.T 1gm of Sodium Pentothal diluted to $1000 \mathrm{ml}$ with the distilled water. The dissolved solution was administered intravenously along with $10 \%$ of dextrose with the help of anaesthetic. The rate of administration was controlled so as to drive the terrorist slowly into a state of trance. The revelations made by the suspected terrorist only during the state of trance were video recorded. The questions were repeated persistently in order to reduce the ambiguities during the Narco analysis test. The information so revealed was further cross checked by subjecting the suspected terrorists to the Brain Mapping test.

\section{Physiological recording}

An Electroencephalogram (EEG) from 12 sites were recorded using discrete electrodes during Narco analysis. A high pass filter of $0.016 \mathrm{~Hz}$ and a low pass filter of $60 \mathrm{~Hz}$ were used for recording. Horizontal and vertical Electrooclograms (EOGs) were recorded from above and below the left eye. The electrodes were attached to forehead connecting to the BIS monitor. ECG was also continuously monitored during the entire procedure of Narco analysis.

\section{Results}

The revelations of information's by the suspected terrorists during the Narco analysis examination, information collected during preliminary interaction, and the questionnaire administered were statistically analyzed for understanding the level of motivation of the individual and how it is different from one another (Table 1).

\section{Age}

It has been found from the table- 1 that the terrorists in the present study were in the age group of 18-26 years old. These terrorist were in early adulthood. They were unable to make proper decisions became susceptible to social influences of the organized group. Russell \& Miller $^{5}$ found that the average age of an active terrorist member (as opposed to a leader) was between 22 and 25, except for Palestinian, 
German, and Japanese terrorists, who were between 20 and 25 years old. Another source explains that the first generation of RAF terrorists went underground at approximately 22 to 23 years of age, and that the average age shifted to 28 to 30 years for second-generation terrorists (June Second Movement). In summarizing the literature about international terrorists in the 1980s, Taylor ${ }^{6}$ characterizes their demography as being in their early twenties and unmarried and noticed considerable variability from group to group. LTTE, having many members in the 16- to 17 year-old age level and even members who were preteens. Laqueur ${ }^{7}$ notes that Arab and Iranian groups tend to use boys aged 14 to 15 for dangerous missions. In the present study terrorists in the above mentioned age group were selected because they never asked any questions, followed the instructions blindly and never attracted the attention of the public in the accomplishment of their target.

Table I Shows demographic details of suspected terrorists who were subjected for Narco analysis test

\begin{tabular}{|c|c|c|c|c|c|c|}
\hline $\begin{array}{l}\text { Terror } \\
\text { suspects }\end{array}$ & Age & Education & SE status & $\begin{array}{l}\text { Association with } \\
\text { terrorist organization }\end{array}$ & $\begin{array}{l}\text { Undergone } \\
\text { training }\end{array}$ & Addictions if any \\
\hline A & 26 & student (engineering) & Middle & 3yrs & $2 \mathrm{yrs}$ & nil \\
\hline B & 21 & student B.A(incomplete) & Middle & $2 y r s$ & nil & watching TV for long \\
\hline C & 24 & school drop out & Lower & $5 y r s$ & 3yrs & smoke occasional \\
\hline D & 23 & student (diploma) & Middle & $2 y r s$ & 6 mths & smoke \\
\hline E & 19 & $9^{\text {th }}$ fail & Lower & lyr & lyr & watching TV for long hours \\
\hline $\mathrm{F}$ & 22 & School drop out & Middle & $2 y r$ & $2 y r$ & watching TV for long hours \\
\hline G & 18 & $10^{\text {th }}$ fail & Middle & $\mathrm{IYr}$ & lyr & watching TV for long hours \\
\hline $\mathrm{H}$ & 23 & $8^{\text {th }}$ fail & Middle & $5 y r s$ & $4 y r s$ & watching TV for long hours \\
\hline I & 23 & $\begin{array}{l}\text { no formal schooling able } \\
\text { to read }\end{array}$ & Lower & 5 yrs & 3 yrs & watching TV for long hours \\
\hline J & 20 & Islamic studies & Middle & $\mathrm{l} y \mathrm{r}$ & $\mathrm{l} \mathrm{yr}$ & nil \\
\hline
\end{tabular}

\section{Education}

Terrorists in general have more than average education, and very few Western terrorists are uneducated or illiterate. In the present study, terrorist associates were found to be students, school dropouts, failed in High school but all of them were literates i.e. able to read and write. Russell \& Miller ${ }^{5}$ found that about two-thirds of terrorist group members had some form of university training. Highly educated terrorists were normally given leadership positions, whether at the cell level or at the national level. The occupations of terrorist leaders have likewise varied. The terrorists group Leaders frequently were professionals such as doctors, bankers, lawyers, engineers, journalists, university professors, and mid-level government executives. The PLO's Yasir Arafat was a graduate engineer. Mario Santucho was an economist. Raúl Sendic and the Baader-Meinhof's Horst Mahler were lawyers. Urika Meinhof was a journalist. The terrorist in the present study were students, had little education and joined a terrorist group out of boredom with the desirous of an action-packed adventure, such as circuit drawing, assembling of bomb.

\section{Socio-economic status}

In the present study more than two-thirds of the terrorists have come from middle-class back grounds and only 3 of them were from the Lower class back ground. Findings of the present study is similar to that of Russell \& Miller ${ }^{5}$ a higher number of terrorists are from middle-class back ground and few of them are even from lower-class backgrounds. Palestinian or Islamic fundamentalist organizations, terrorists come from middle-class families. European and Japanese terrorists are highly educated and from upper class back ground. People at the younger age in this study reported to have been attracted to terrorism over the plight of the world's poor population. Terrorists in much of the developing world tend to be drawn from the lower sections of society. In the present study, analysis of the data has indicated that poor achievement, financial failure and limited earning potential have encouraged them to join the terrorist group.

\section{Associations with the terrorist organization}

It was somewhat misleading to regard many terrorists in the present study as former professionals. These terrorists have been able to remain anonymous and probably continue to practice their legitimate professions and moonlight as terrorists till they receive instructions to carry out a mission. In the present study, to hide their identity, many of the suspects were treated as "sleeping commandos." These men were passive members leading normal lives with their regular jobs but after work they are trained for specific missions. They were unaware of each other's real identities and receiving coded instructions from an anonymous source. After carrying out their assigned tasks they had resumed their normal lives. Thus all of the above suspects from Table 1 had association with terrorist organizations and were trained for the specific missions. All the above except one had undergone training for various periods ranging from 6 months to 4 years before they were assigned for the tasks in the mainstream of mission. The occupations of terrorist recruits are varied widely. There doesn't appear to be any particular occupation that produces terrorists. It was found that the individual, often with the help of a family member or friend with terrorist contacts, turns to be a member of terrorist group thus training from a terrorist organization in the present study was found to be a gradual process. However, after a period of an year or more, a recruit generally moves in a slow, gradual fashion toward full membership in a terrorist group. 


\section{Addictions}

Terrorists are generally people who feel alienated from society and have a grievance or regard themselves as victims of an injustice and prefer any isolated actions. From the table 1 above it is seen that that suspects watch the TV for a long hours. On inquiry they revelled that they enjoy watching programs related to violence and do not regard violent actions as criminal. The physiological approach to terrorism suggests that the role of the media in promoting the spread of terrorism cannot be ignored in any discussion of the causes of terrorism. Thanks to media coverage, the methods, demands, and goals of terrorists are quickly made known to potential terrorists, who may be inspired to imitate them upon becoming stimulated by media accounts of terrorist acts. Other than watching violent action through internet and crime stories in television, smoking was their other major addiction.

\section{Discussion}

\section{Motivation}

An understanding of the terrorist mindset, motivation would be the key to understanding of how and why an individual becomes a terrorist. The purpose of this study is to focus attention on the types of individual's motivation and how it differs from the organizational motivation. This study is an effort to help government to improve counterterrorist methods and policies. Psychologists have been unable to adequately define differences in individual motivation and organizational motivation. Indeed, there appears to be a general agreement among psychologists who have studied the subject that there is no one terrorist mindset (Table 2).

Table 2 Showing different individual motivation

\begin{tabular}{ll}
\hline No. & Motivations \\
\hline 1 & Perception as victims of social injustice \\
2 & Religion \\
3 & Identities \\
4 & Belongingness \\
5 & Political repression \\
6 & Heroism \\
7 & Autonomy \\
\hline
\end{tabular}

\section{Perception as victims of social injustice}

Injustice is recognized as a central factor in justifying terrorism specifically with reference to the present study. Hacker ${ }^{8}$ concluded that "remediable injustice is the basic motivation for terrorism". A desire for revenge or vengeance was the common response obtained from the entire sample of the above suspected terrorist reference to Table 2. They perceives them self as a victim in society. Their logic is external forces are causing unhappiness and making it hard to succeed. The grievances were economic, political, religious and social, and they have targeted individuals, and groups of people who they thought are responsible for the injustice. The present findings are similar to the findings by Crenshaw ${ }^{9}$. Their belief is that their target produced disharmony in society in term of unbalanced economic growth, communication structure, and lack of political opportunity etc. Therefore, it is not difficult to imagine that "one of the strongest motivations behind terrorism is vengeance, particularly the desire to avenge not one but others. ${ }^{9}$

\section{Religion}

It is believed that terrorism is a manifestation of religious fanaticism. Unable to achieve their unrealistic goals by conventional means, terrorists attempt to send an ideological or religious message by terrorizing the general public. The religion serves as an instrument in the hands of Muslim terrorists in order to justify their actions, and to provide moral explanations to their inhumane actions. Once a young man has "crossed the threshold" and begun the indoctrination process, his information environment changes dramatically. He is isolated and indoctrinated and his worldview gets altered. Once a potential recruit has entered the pipeline, he is no longer an appropriate target for counter radicalization through positive influence, because he is unlikely even to hear an opposing message, and the chance that he will be free to respond to it or interpret it objectively is nil. The entire group of suspected terrorists in the present study in reference to Table 2 expressed religion as one of the major motives for terrorism. Religion and Islam in particular is used by agencies as informed by the suspected terrorists in the present study to recruit, fight and justify their actions. Religion does plays an important role. A study conducted by Anneli Botha ${ }^{10}$ at the Institute for Security Studies (ISS) shows that $87 \%$ of respondents gave religion as the reason why they joined al Shabab. There is no indication in the Qur'an for the word terrorism. The religious sages uses fatwas (legal pronouncement that is not binding to all Muslims) and their religious authority in order to justify terrorism as a necessary means for meeting the needs of reality. "Terrorists take refuge in religion which determines goals; they find physical or psychological sanctuary against repression; or they may use it as a major instrument for activism and for political action." According to Magnus Ranstorp, Culture on the other hand, provides the collective identity and the social behavior that legitimizes and supports terrorism as well as creates the necessary environment to recruit activists and to raise funds. Without the proper culture, religion by itself cannot be used as an adequate reason for terrorist attacks. Thus, the combination of religion and culture can generate the set of beliefs and values that motivate Islamic terrorism and produce social unity, regardless of the religious fervor of the community members. As religion and culture are intertwined, one should explore them together and put them in the political and socio-economic context in order to be able to comprehend the real nature of Global Jihad. There are important facts concerning religious education. The prevailing characteristic of the subjects in the present study is incorrect or incomplete religious education during their formative years. The lack of a complete understanding of their own faith made the subjects vulnerable to Terrorist Organisation skewed appeal. Reintegration programs in Saudi Arabia, the Netherlands, Singapore, and Indonesia have successfully rehabilitated former extremists by directly refuting al-Qaeda's religious interpretations with knowledgeable Islamic scholars. If reeducation through religious teaching can cause a fighter to renounce al-Qaeda, it stands to reason that religious education programs conducted with younger participants could inoculate them against the appeal of al-Qaeda. The government should actively support clerics whose interpretations of Islam support peaceful coexistence. These ideas are active throughout the Muslim world, but their voices must be amplified, rebroadcast, and retransmitted to wider audiences.

\section{Identity}

Identity is the answer to the question "who am I really?" One's psychological identity is a developed, stable sense of self and resolved 
security in one's basic values, attitudes, and beliefs. Some individuals are unable or unwilling to identify with any one for a long period of time. This unsatisfied identity needs may be manifested in many ways. In the present study from Table 2 the entire group of suspected terrorists reported negative identity and identity crisis as one of the major motivational factors in joining the terrorism. Individuals adopt someone's identity without personal and critical examination. Rejection of the role regarded as undesirable by an individual's family and community, develops a negative identity due to feeling of rage and helplessness without any alternatives. As a result of that, an individual get attracted to the terrorist organizations to search for his identity. Under desperate quest for personal meaning, it becomes easier for such individual to adopt a negative role. They identify as a "terrorist" or "freedom fighter' to answer the question. One's personal identity thus gets merged with a group identity, with no sense of (or need for) individuality or uniqueness. As Johnson \& Feldman ${ }^{11}$ suggest, "membership in a terrorist group provides a sense of identity or belonging for those personalities whose underlying sense of identity is flawed." For these individuals, "belonging to the terrorist group becomes the most important component of their psychosocial identity". ${ }^{2}$ Being part of something is the principal motivation for the identity seeker. Psychologist Jeanne N Knutson ${ }^{13}$ suggests that the political terrorist consciously assumes a negative identity. Negative identity is a rejection of the role by family and community is regarded as desirable and proper by an individual.

\section{Belongingness}

In radical extremist groups, many prospective terrorists find not only the sense of meaning, but also the sense of belonging and connectedness. Luckabaugh \& colleagues $^{14}$ argue that among potential terrorists "the real cause or psychological motivation for joining is the great need for belonging." You belong; therefore, you exist. ${ }^{8}$ Those individuals have experienced lifetime of rejection; for instance family rejection, social rejection, peer rejection etc, and joining terrorist organization give them a new sense of belonging. Terrorist group may become new family for that people..$^{15}$ In the present study, $80 \%$ of suspect terrorists expressed their need to belong to a group. They needed the structure, rules and the perspective that come from belonging to a group because belonging defines his role, his friends, and his interaction with society. This motivated most of the terrorists to join a terrorist group. Behavior among terrorist's suspects is similar, because of this need by alienated individuals to belong. For the new recruit, the terrorist group becomes a substitute family, and the group's leaders become substitute parents. Thus a key motivation for membership in a terrorist group is the sense of belonging and the fraternity of like-minded individuals. As the group comes under attack from security forces, the tendency would be for the group to become more cohesive.

\section{Political activity}

Terrorists reported having been unsuccessful in obtaining a desired traditional place in society, and this has contributed to their frustration. They develop crisis in their psychosocial identity. The underlying need to belong to a terrorist group is symptomatic of an incomplete or fragmented political identity. Around 50 percent of the suspected terrorist in the study reported political repression as their motivational factors in joining the terrorist activity. The personal pathway model suggests that terrorists came from a selected, at risk population, who had suffered from early damage to their self-esteem.
Their subsequent political activities may be consistent with the liberal social philosophies of their families, but go beyond their perception of the contradiction in their family's beliefs and lack of social action. Family political philosophies may also serve to sensitize these persons to the economic and political tensions inherent throughout modern society. The security forces or police are cited as provoking more violent political activity by these individuals.

\section{Heroism}

In the present study, around $40 \%$ of the individuals have reported a desire and motivation to become a hero. They believed to have special skills and leadership qualities which distinguish them from others in the group. They reported to have the ability to use a variety of weapons, vehicles, and communications equipment and were familiar with their physical environment. Post ${ }^{15}$ argues that "individuals become terrorists in order to join terrorist groups and commit acts of terrorism." Joining a terrorist group gives them a sense of "revolutionary heroism" and self-importance that they previously lacked as individuals. Consequently, a leader who is action-oriented is likely to have a stronger position within the group than one who advocates prudence and moderation. Thomas Strentz ${ }^{16}$ has pointed out that terrorist groups that operate against democracies often have a field commander who he calls an "opportunist," that is, an activist, usually a male, whose criminal activity predates his political involvement. Strentz ${ }^{16}$ applies the psychological classification of the antisocial personality, also known as a sociopath or psychopath, to the life-style of this type of action-oriented individual. Although the opportunist is not mentally ill, Strentz ${ }^{16}$ explains, he "is oblivious to the needs of others and unencumbered by the capacity to feel guilt or empathy."

\section{Autonomy}

Uncertainties about one's life and with newly acquired freedom suspect terrorists became susceptible to ideology that requires aggressing against themselves or against others. Around $40 \%$ of the above suspected terrorists from Table 2 said that they were motivated to distance themsevles from the family and social network. During such lonely and transitional life they were influenced by the organized group with leaders as their parental figures and action oriented messages became more appealing. In asserting their autonomy they try out autonomy resulted in rebellion behavior the new roles without thinking consequences of their actions. Such quest for individual autonomy resulted in rebellion behaviour.

\section{Theories of motivation}

\section{Identity theory}

It has been seen from the present study that some younger generation who became terrorists were attracted towards the terrorism in search of an identity. This self-driven, self-motivated behavior of the individuals to join the terrorist organization can be explained using Identity theory. Olsson, in his books-'The Terrorist and the Terrorized stated that: Some psychoanalytic consideration' has proposed that young people often lack self- esteem and have strong or even desperate needs to consolidate their identities. This has attracted them towards terrorism. In the present study, 13 individual had an identity crisis. Studies have indicated that individuals with identity crisis seeking a sense of purpose and self-worth often end up in the path of violence. In this path of seeking identity, the ideologies of a terrorist organization were to assist those identity confused 
individuals to the path of violence. The emphasis of the violent acts of terrorism highlighted in the news and social media across the world, lures such identity crisis minds easily towards it. Once the individuals are attracted towards the organization, the process of radicalization begins leading to the conversion of the individuals into terrorism. The perceived belief is that following the path of extremism/terrorism will help to solve their identity crisis. The terrorist organization also helped them in answering the identity questions which arose in the subject's mind. By answering these identity related questions the subjects defined themselves as a terrorist and thus fulfill the objectives of the terrorist organization. ${ }^{10}$

\section{Humiliation-revenge theory}

The revelations made during Narco analysis in the present study had indicated information provided regarding the atrocities against the Muslims in various parts of the world and thus atrocity had triggered the individuals to choose the path of terrorism. The incidents revealed by them such as destruction of Babri masjid, Gujarat communal riots and the mass killings of Muslims in Palestine and Afghanistan are often found to act as triggers in provoking them to join a terrorist organization. The perceived belief that the people of other religions such as Jews, Christians and Hindus are disrespecting the Islam and the role of westernization in the changing life style of Muslims, leads to a sense of feeling that Islam religion is humiliated. This humiliation feeling had led to revenge and had driven the individuals towards the violent path of terrorism. A majority of the terrorists, in this study, were found to be motivated by the revenge against the society. 4 individuals in the present study were found having revengeful attitude which was a motivating factor to join the terrorist organization. Juergensmeyer, in his publication-'Terror in the Mind of God' hypothesized that Humiliation-and the consequent internal pressure for revenge-is a psychological factor that has been found to motivate and drive terrorist violence (Juergensmeyer). ${ }^{11}$ In fact, revenge for humiliation by an oppressor is an ancient cultural tradition which directly links to the current violence in the Middle East and the same is observed in the home-grown terrorists of India. The revenge seeker who effectively vents his aggressive frustrations on the playing field is less susceptible to messages that tap unfocused rage. This perspective of the theory can be associated with that of Palestinian psychiatrist Eyad el Sarraj, who has specifically observed that humiliation is an important factor motivating young suicide bombers. Similarly, Dr. Abdul Aziz Rantisi, the late political leader of Hamas, also confirmed this notion in a statement published three years before his death via targeted killing by the Israeli Defense Forces: "To die in this way is better than to die daily in frustration and humiliation". ${ }^{17}$

\section{Group socialization theory}

The majority of the terrorists are motivated in the group by the group. The individuals who are attracted towards the terrorist organizations are made to spend most of their time with the members of the organization. They are often made to involve themselves in the activities of the terrorist organization by creating an environment which acts as a catalyst to provide the individuals a sense of togetherness. In the present study, it has been observed that all the terrorists were subjected to process group socialization. Group socialization theory states that an individuals' peer groups, rather than any other figures such as parents, friends, etc., influences the personality and behaviour .This very principle of the psychology is seen to be utilized by the terrorist organizations in the process of radicalization to motivate the individuals of the group. The attitude of the terrorist organization towards the society, their perceived beliefs and values circulates inside the group of individuals as a chain reaction by creating an environment which facilitates to the change in attitude of the individuals to synch with that of terrorist organizations.

The terrorist organizations are said to give people the feeling of belongingness and family that the individuals had been searching for. They create an environment inside the organization such that the individuals who were isolated and lost, feel like that they have found a perfect home. This feeling of belongingness which the individuals get after joining the terrorist organization is what motivates them, remain in and act on behalf of the terrorist organization..$^{10,17,18}$ In this study, 13 individuals who joined the terrorist organizations have been found to have feelings of alienation from the rest of the world. Thus radicalization of individuals and motivating to join a terrorist organization is influenced by various factors. These factors may differ from individual to individual depending on their mental state and the environment they live in the society.

\section{Conclusion}

Terrorists attacks has its impact globally-be it tourism, Gross Domestic Product, medical industry, productivity, aviation industry, stock market etc. Terrorism creates feeling of frustration in the society with the main objective of destruction. The urgent need is to fight against terrorism. It cannot be wiped out by few hands or by force of arms. It has to be by combination of government governance, stringent laws, and a quick and firm system of justice. National strategy is to understand the level of threat and to find out the way it should be dealt at all levels. The state has a responsibility towards public safety, justice dispensation and prevention of crime as compelling state interest. Terrorism in general has many motivations depending on the special interests of the individual or cells. Common characteristics or clearly defined traits have been indicated in simple comparisons in the present study but detailed study is required to identify those significant contrasts that are more often the norm. ${ }^{19,20}$ Behavior of a terrorist varies depending on their ideological commitment, individual intelligence, education, finance, geographical setting and organizational reach. There are important facts from reeducation and reintegration programs, concerning religious education. The prevailing characteristic of the subjects studied demonstrated incorrect or incomplete religious education during their formative years. The lack of a complete understanding of their own faith made the subjects vulnerable to al-Qaeda's skewed appeal. Reintegration programs in Saudi Arabia, the Netherlands, Singapore, and Indonesia have successfully rehabilitated former extremists by directly refuting al-Qaeda's religious interpretations with knowledgeable Islamic scholars. If reeducation through religious teaching can cause a fighter to renounce al-Qaeda, it stands to reason that religious education programs conducted with younger participants could inoculate them against the appeal of al-Qaeda. The individuals are motivated through a gradual process where they emerge out as a changed person with changes in their belief and attitude. This motivation is what initiates, guides and maintains a goal oriented behavior of the terrorists. The motivation factors cannot be generalized, it varies from one another. In the present study it was found that there were different motivating factors for radicalization that were identified. There are revenge seekers looking for an outlet for their frustration, status seekers looking for recognition, identity seekers looking for a group they can belong to, and thrill seekers looking for adventure. Some terrorists were found to be self-motivated and some were motivated by the organization but all were found working towards for the common 
objective of the terrorist organization.

The young men under study who were attracted to terrorist organization displayed the emotional struggle for purpose, direction, and identity that is common in adolescent development in most cultures. Their experiences and surroundings have shaped them, but their desire to establish a role in society, and the thwarting of that desire are the true catalyst for their affiliation with terrorist organizations. From the present study, it can concluded that injustice, religion, identity, belonging, political activity, heroism and autonomy can be seen as strong influence and real causes of psychological motivation for individual joining and staying with terrorist groups. ${ }^{21,22}$ This study is an effort to help the Government to improve counterterrorist methods and policies by making an attempt to clarify each Individual's motivations and explain how individuals view the world. The principal contribution of this study is a prevention-andcommunications strategy targeting the specific mental framework and psychological needs of each type of seeker by designing religious counseling and guidance to reduce the number of youths who are highly susceptible to radicalization. Following the revelations in the Narco analysis material evidences were recovered in the July 11, 2006 blasts case. Of the 13 who faced trial, one was acquitted, 12 men were convicted by the designated court. The convictions were for conspiracy and committing offences against the country in an organized manner. The crime had attracted a maximum punishment of death for 5 terrorists and life imprisonment for the remaining 7 terrorists.

\section{Acknowledgements}

None.

\section{Conflict of interest}

The author declares no conflict of interest.

\section{References}

1. Moghaddam FM, Marsella An J. Understanding terrorism: Psychosocial roots, consequences, and interventions. Washington DC: American Psychological Association; 2000:169-185.

2. Clark McCauley, Sophia Moskalenko. Mechanisms of political radicalization: Pathways toward Terrorism. Terrorism and Political Violence. 2008;20(3):415-433.

3. Hanscom CB. Narco Interrogation. Journal of forensic sciences. $1956 ; 1: 37-45$.

4. Manu Sexena. Investigation and Law. 2015.

5. Russell CA, Millers BH. Profile of a terrorist on Research Gate. Professional net work for Scientist. 1(1):1977.
6. Taylor DM, Louis W. Terrorism and the quest for identity. American Physiological Association. 2004:169-185.

7. Walter Laqueur. Work on terrorist. Sage Publication. 1998;3:2040-2042.

8. Hacker FJ. Crusaders, criminals, crazies: terror and terrorism in our time. New York: WW Norton; 1976:371.

9. Crenshaw M. How terrorists think: Psychological contributions to understanding terrorism. In: Howard L, editor. Terrorism: Roots, impact, responses. London: Praeger; 1992:71-80.

10. Anneli Botha. Root causes of violent extremism and Terrorism. Ph. D thesis, University of Free State. 2014.

11. Johnson PW, Feldman TB. Personality types and terrorism: Selfpsychology perspectives. Forensic Reports. 1992;5(4):293-303.

12. Post JM. "It's us against them": the group dynamics of political terrorism. Terrorism. 1987;10(1):23-35.

13. Jeanne N Knutson. The terrorist dilemmas: some implicit rules of the game. Terrorists: 1980;4:1-4.

14. Luckabaugh Robert, Edward Fuqua, Joseph Cangemi, et al. Terrorist behavior and US foreign policy: Who is the enemy? Some psychological and political perspectives. Psychology. 1997;34(2):1-15.

15. Post JM. Notes on a psychodynamic theory of terrorist behavior. Terrorism. $1984 ; 7(2): 241-256$.

16. Thomas Strentz. Psychological aspects of crisis negotiation. USA: CRC press; 2005:290-296.

17. Horgan, J, Taylor M. The making of a terrorist. Jane's Intelligence Review. 2011;13(12):16-18

18. Borum R. Psychology of terrorism. Tampa: University of South Florida; 2004:1-80.

19. Marc Sageman. Leaderless Jihad. Philadelphia: University of Pennsylvania Press; 2008:208.

20. Charles A Russel, Captain Bowman H Miller. (USAF), Profile of Terrorist, Military review. Sage Publication. 1977:21-34.

21. Crenshaw M. The psychology of political terrorism. In: Hermann MG, editor. Political psychology: contemporary problems and issues. London: Josey-Bass; 1986:379-413.

22. Srenshaw M. The subjective reality of the terrorist: Ideological and psychological factors in terrorism. In: RO Slater, M Stole, editors. Current Perspectives in international terrorism. Basingstoke, Hampshire: Macmillan; 1988:270. 